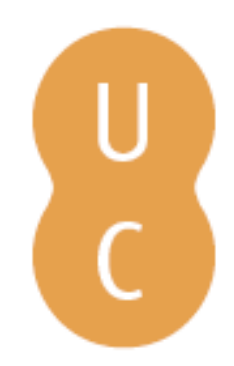

\title{
pommalina
}

\section{Estudo do usuário e suas implicações para a consecução do informar-se}

\author{
Autor(es): $\quad$ Barros, Maria Helena T.C. de \\ Publicado por: Imprensa da Universidade de Coimbra \\ URL \\ persistente: URI:http://hdl.handle.net/10316.2/31943 \\ DOI: $\quad$ DOI:http://dx.doi.org/10.14195/978-989-26-0869-3_32
}

Accessed : $\quad$ 26-Apr-2023 13:28:13

A navegação consulta e descarregamento dos títulos inseridos nas Bibliotecas Digitais UC Digitalis, UC Pombalina e UC Impactum, pressupõem a aceitação plena e sem reservas dos Termos e Condições de Uso destas Bibliotecas Digitais, disponíveis em https://digitalis.uc.pt/pt-pt/termos.

Conforme exposto nos referidos Termos e Condições de Uso, o descarregamento de títulos de acesso restrito requer uma licença válida de autorização devendo o utilizador aceder ao(s) documento(s) a partir de um endereço de IP da instituição detentora da supramencionada licença.

Ao utilizador é apenas permitido o descarregamento para uso pessoal, pelo que o emprego do(s) título(s) descarregado(s) para outro fim, designadamente comercial, carece de autorização do respetivo autor ou editor da obra.

Na medida em que todas as obras da UC Digitalis se encontram protegidas pelo Código do Direito de Autor e Direitos Conexos e demais legislação aplicável, toda a cópia, parcial ou total, deste documento, nos casos em que é legalmente admitida, deverá conter ou fazer-se acompanhar por este aviso.

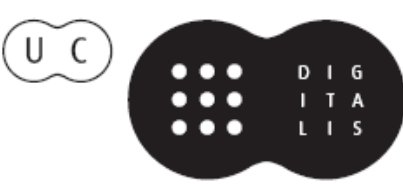


Maria Manuel Borges

Elias Sanz Casado

Coordenação

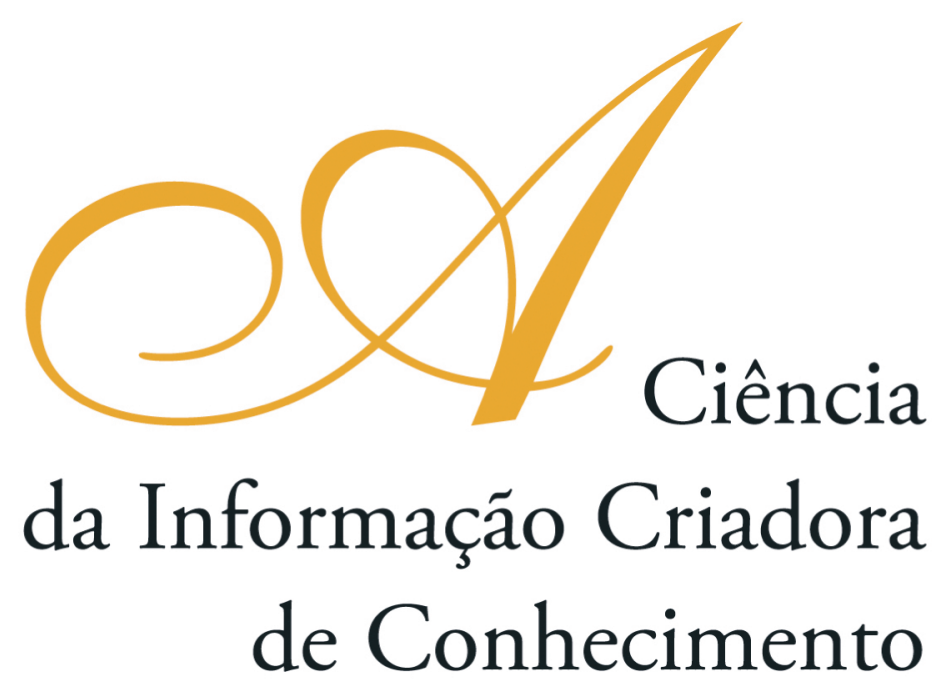

Vol. I I

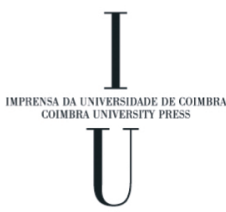

- COImbra 2009 
Maria Helena T.C. de Barros

Universidade Estadual Paulista (Brasil)

\section{Introdução}

O universo da informação está sendo afetado pela rápida aceleração das mudanças que ocorrem no nosso mundo globalizado. Mais do que nunca, nós vivemos numa era da informação, na qual ela é matéria-prima estratégica, ao fazer a diferença em qualquer setor, sob o ponto de vista individual ou coletivo; local, regional ou global. Nesse sentido, a consecução do informar-se e suas implicaçôes adquirem uma notável relevância.

\section{Objetivos e Metodologia}

O principal objetivo deste trabalho é discutir certas observaçóes, experiências e resultados de uma prática acadêmica, envolvendo o contexto das salas de aula em Curso de Biblioteconomia, de um lado, e a sociedade que é servida e provida de informação pelos bibliotecários e suas equipes, de outro; quais sejam, os atores que se envolvem na busca da informação e no acesso ao conhecimento. Para tanto, buscouse inspiração metodológica em Sócrates e nos diálogos socráticos, descritos como maiêutica pelos seus discípulos para, a partir da declaração de ignorância, ser possível atingir o conhecimento, a sabedoria e a verdade de cada um.

\section{Resultados e Discussão}

Ao final, destacam-se os seguintes pontos que envolvem a disciplina Estudo do Usuário e outras da mesma "família" nessa relação:

- mudança no paradigma do texto para a informação

- ligação intrínseca entre sala de aula - biblioteca

- observação crítica dessa inter-relação

- atendimento, pelo bibliotecário, de usuários da informação, inclusive aqueles desprovidos de familiaridade com os setores, serviços e facilidades oferecidos pela biblioteca

- hiato na formação em Biblioteconomia quanto à educação do usuário/capacitação informacional

- inconsistente história de biblioteca escolar, bem como de capacitação informacional ligadas ao ensino público brasileiro, decorrentes das políticas públicas para o setor

- ligação "quase atávica" que vincula os dois atores e parceiros relacionados com a informaçáo: o bibliotecário e o usuário-consumidor. 


\section{Referências bibliográficas}

Cotrim, G. (2006). Fundamentos da filosofia: história e grandes temas (16a ed.). São Paulo: Saraiva.

Dorion, L.A. (2006). Compreender Sócrates (Orth, L.M.E., trad.). Petrópolis-RJ: Vozes.

Encyclopedia e Diccionàrio Internacional. (s.d.). Rio de Janeiro: São Paulo: Porto Alegre: W.M. Jackson.

Sans Cazado, E. (1994). Manual de estúdios de usuários. Madrid: Pirâmide.

UNESP. Faculdade de Ciências Agrárias e Veterinária. Pesquisa Bibliográfica e Técnicas de Redação.(s.d.). Depoimentos avaliativos de pós-graduandos. Jaboticabal-SP (mimeo).

UNESP. Faculdade de Filosofia e Ciências/Campus de Marília. (2006). Plano de Ensino: Estudo de Usuários. Marília: UNESP (mimeo). 